НАУКОВИЙ ВІСНИК Ннального унввереит імені с.з. Гжицьиого Scientific messenger of Lviv National University of
Veterinary Medicine and Biotechnologies

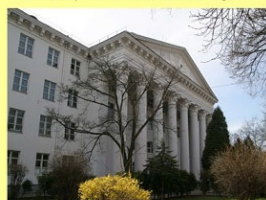
СЕРЯЯ “ЕКОНОМІЧн НАУКИ“ Том 23 № 97 2021
Науковий вісник Львівського національного університету ветеринарної медицини та біотехнологій імені С.3. Гжицького. Серія: Економічні науки

\author{
Scientific Messenger of Lviv National University \\ of Veterinary Medicine and Biotechnologies. \\ Series: Economical Sciences
}

ISSN 2519-2701 print https://nvlvet.com.ua/index.php/economy doi: $10.32718 /$ nvlvet-e9708

UDC 658.0:338

\title{
Income formation of hunting farms of Zaporizhia region
}

\author{
O. O. Sobolevska
}

Separate structural subdivision of Higher Education Institution "Open international iniversity of human development "Ukraine” Melitopol institute of ecology and social technologies, Melitopol, Ukraine

Article info

Received 28.09.2021

Received in revised form 28.10.2021

Accepted 29.10.2021

Separate structural subdivision of Higher Education Institution

"Open international iniversity of human development «Ukraine»

Melitopol institute of ecology and social technologies,

Interkulturna Str, 380, Melitopol

72316, Ukraine

Tel.: +38-096-610-75-71

E-mail: olgas140583@gmail.com
Sobolevska, O. O. (2021). Income formation of hunting farms of Zaporizhia region. Scientific Messenger of Lviv National University of Veterinary Medicine and Biotechnologies. Series: Economical Sciences, 23(97), 41-47. doi: 10.32718/nvlvet-e9708

The relevance of the study of the dynamics and structure of income of hunting farms in the region. It is determined that this study is one of the main tasks of the analysis of enterprise income. The classification and structure of incomes of hunting farms are given. The dynamics in the formation of the number of users of hunting lands of Zaporizhia region and their structure in terms of state enterprises, public organizations and private enterprises are analysed. There is a tendency to reduce the area of hunting grounds in state farms and public organizations and increase - in private enterprises. An analysis of the financial performance of hunting farms in general, which showed that the level of cost recovery income in the Zaporizhia region among other regions of Ukraine is one of the highest. A similar analysis in terms of different organizational forms of hunting management showed the lowest level of cost recovery for users who belong to other private and public hunting organizations. In 2019 it was $55.9 \%$ compared to $63.8 \%$ in the organizations of the Ukrainian Society of Hunters and Fishermen and $74.4 \%$ in the enterprises of the State Forest Agency of Ukraine. The structure of sources of income of hunting farms is given, among which the main ones are income from the sale of licenses for hunting animals, sale of shot cards for fur, sale of shot cards for game birds, sponsorship, and other income. The dynamics of the total number and number of captured wild animals by their different species is analysed. It is shown that the most significant share of income of hunting farms in Zaporizhia region is provided by the number of ungulates, which remains low in the region. During the period from 2015 to 2019, it decreased from 52 to 19 animals. It is established that the formation of income of hunting farms is influenced by the following negative factors: high level of poaching, shadow component of the economy, imperfection of the legal framework and statistical reporting, reduction of hunting grounds, reduction of ungulates, insufficient number of qualified specialists. The study found that the almost complete lack of state support for the hunting industry has led to a decrease in the interest of hunting land users in the efficient and rational use of natural resources of the region.

Key words: hunting farms, enterprise income, users of hunting lands, level of cost recovery.

\section{Формування доходів мисливських господарств Запорізької області}

\author{
О. О. Соболевська
}

Відокремлений структурний підрозділ закладу вищої освіти “Відкритий міжнародний університет розвитку людини “Украӥна” Мелітопольський інститут екології та соціальних технологій, м. Мелітополь, Украӥна

Окреслено актуальність дослідження динаміки і структури доходів мисливських господарств у регіональному вимірі. Визначено, шо дане дослідження є одне із основних завдань аналізу доходів підприємства. Наведена класифікація та структура доходів мисливських господарств. Проаналізовано динаміку у формуванні кількості користувачів мисливських угідь Запорізької області та їх структуру у розрізі державних підприємств, громадських організацій та приватних підприємств. Визначена тенденція зменшення площі мисливських угідь у державних господарствах та громадських організаціях та збільшення - у приватних підприємствах. Проведено аналіз фінансових показників діяльності мисливських господарств в цілому, який показав, щзо рівень окупності витрат доходом у Запорізькій області серед інших регіонів Украӥни є одним із найвищих. Аналогічний аналіз у розрізі різних організачійних форм ведення мисливського господарства засвідчив про найнижчий рівень окупності витрат у користувачів, які відно- 
сяться до інших приватних та громадських мисливських організацій. Зокрема, він становив у 2019 рочі 55 , $9 \%$ порівняно із 63,8 \% у організацій Українського товариства мисливців та рибалок та 74,4 \% - підприємствах Державного лісового агентства Украӥни. Наведена структура джерел доходів мисливських господарств, серед яких основними є: доходи від реалізації ліцензій на добування мисливських тварин, реалізація відстрільних карток на хутрові, реалізачія відстрільних карток на пернату дичину, спонсорська допомога та інші надходження. Проаналізовано динаміку загальної чисельності та кількості добутих диких тварин за різними їх видами. Показано, шчо найбільш значну частку доходів мисливських господарств Запорізької області забезпечує кількість добування копитних тварин, яка у регіоні залишається на низькому рівні. За період із 2015 по 2019 рр. вона скоротилася із 52 до 19 голів. Встановлено, шео на формування рівня доходів мисливських господарств впливають наступні негативні фактори: високий рівень браконьєрства, тіньова складова економіки, недосконалість нормативно-правової бази та статистичної звітності, скорочення площу мисливських угідь, зниження чисельності добування копитних тварин, недостатня кількість кваліфікованих спеціалістів тощо. У процесі дослідження визначено,щу майже повна відсутність державної підтримки мисливської галузі призвела до зниження зацікавленості користувачів мисливських угідь у ефективному і раціональному використанні природних ресурсів регіону.

Ключові слова: мисливське господарство, дохід підприємства, користувачі мисливських угідь, рівень окупності витрат.

\section{Вступ}

Основна мета діяльності будь-якого підприємства полягає в отриманні прибутку, який безпосередньо залежить від доходів. Дохід - $є$ надходженням економічних вигод, які виникають в результаті діяльності підприємства у вигляді виручки від реалізації продукції (товарів, послуг), гонорарів, відсотків, дивідендів тощо. Максимізація доходів в умовах зростання внутрішньої та міжнародної конкуренції, неефективності традиційних форм управління, недосконалості методів та засад державного регулювання, особливо аграрної сфери, є достатньо складним завданням для підприємств різних організаційно-правових форм господарювання.

Теоретичним та практичним аспектам вивчення доходів та прибутковості підприємств, дослідженню ролі різних факторів у їх формуванні присвятили свої працітакі вчені, як Ю. А. Гайбура (Haibura, 2019), О. В. Волошина (Voloshyna et al., 2019), Я. О. Остапенко (Ostapenko \& Morozovskyi, 2020) та ін. Дослідженнями ефективності функціонування мисливської галузі займалися такі науковці як В. Д. Бондаренко (Bondarenko \& Rizun, 2016), В. Музика (Muzyka \& Honta, 2020), Ю. В. Муравйов (Muraviov, 2019), А. С. Торосов (Torosov et al., 2012), А. В. Яворська (Yavorska, 2013), T. I. Яворська (Yavorska \& Sobolevska, 2021).

Незважаючи на те, що діяльності мисливських господарств приділена увага багатьох науковців, деякі питання залишаються недостатньо вивченими. Зокрема дослідження динаміки і структури доходів, факторів їх формування як основні завдання аналізу доходів підприємства, мають велике значення в оцінці ефективної діяльності суб'єктів господарювання у мисливстві та потребують поглибленого розгляду.

Метою статті є теоретичні та практичні аспекти дослідження доходів мисливських господарств Запорізької області та основних факторів їх формування 3 акцентом на джерела доходів.

\section{Матеріал і методи досліджень}

При дослідженні динаміки і структури доходів мисливських господарств було використано дані статистичної звітності за період 2015-2019 рр., оприлюднені на офіційному сайті Державної служби статистики України та статистичні звіти Запорізького обласного управління лісового та мисливського господарства. Аналіз даних проведено з використанням таких загальнонаукових методів, як індукція та дедукція, аналіз та синтез, конкретизація, наукова абстракція. Застосовано також конкретно-економічні методи, такі як порівняння, графічних побудов, абстрактно-логічний та розрахунково-конструктивний методи для вивчення фінансового стану мисливських господарств загалом та у розрізі окремих організаційно-правових форм їх ведення, структури джерел доходів та перспектив підвищення їх обсягу.

\section{Результати та їх обговорення}

Діяльність суб'єкта господарювання повинна супроводжуватися отриманням максимального прибутку, який безпосередньо залежить від рівня отриманих доходів. Доходи набувають особливо важливого значення для підприємств незалежно від форми власності, сфери діяльності та інших факторів. Методика аналізу доходів здійснюється як за доходами в цілому по підприємству, так і за їх джерелами надходження (Voloshyna et al., 2019).

Отже аналіз доходів - це частина економічної стратегії підприємства, яка спрямована на створення економічних умов, що забезпечують відшкодування постійних витрат підприємства, покриття змінних витрат, які залежать від обсягу реалізації продукції, повної і своєчасної оплати всіх видів податків, обов'язкових платежів та забезпечення отримання прибутку (Ostapenko \& Morozovskyi, 2020).

Запорізька область має всі необхідні умови для розвитку мисливства, реалізація яких дасть можливість зробити його не тільки інструментом збереження навколишнього природного середовища, а й джерелом фінансових надходжень до місцевого бюджету. Проте сучасний незадовільний економічний стан мисливських господарств регіону, вимагає всебічного аналізу показників їх фінансової діяльності, а саме отримання доходів, які в подальшому впливають на життєвий цикл господарства.

Згідно з чинним законодавством,ведення мисливського господарства в Україні здійснюється користувачами мисливських угідь (державними підприємствами, громадськими організаціями, приватними підприємствами). Відповідно до Закону користувачі мисливських угідь - спеціалізовані мисливські господарства, інші підприємства, установи та організації, в яких створені спеціалізовані підрозділи для ведення мисливського господарства 3 наданням у їх користування мисливських угідь (Muzyka \& Honta, 2020; Pro myslyvske hospodarstvo..., 2000). 


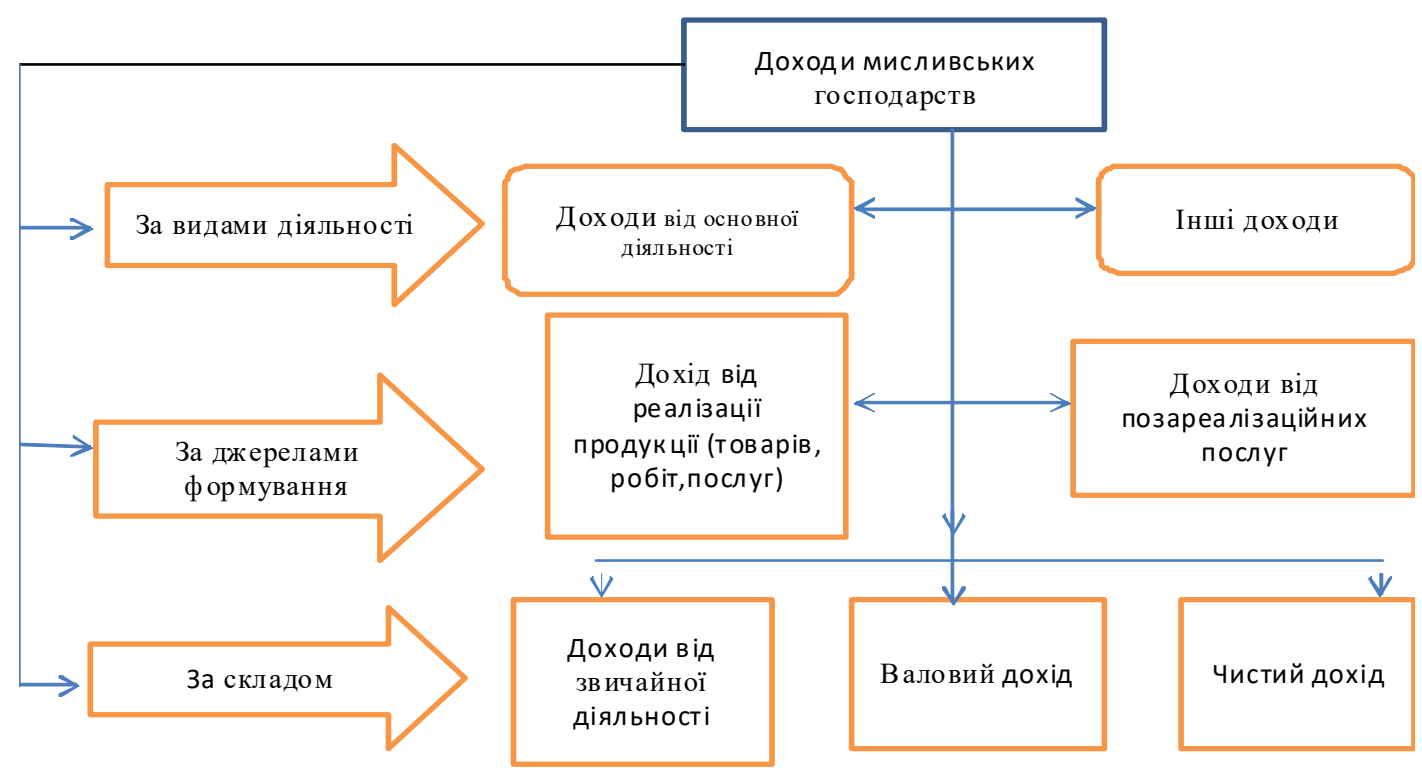

Рис. 1. Класифікація та структура доходів мисливських господарств Джерело: розроблено автором на основі (Pro zatverdzhennia form derzhavnykh..., 2017)

Сьогодні мисливське господарство у Запорізькій області ведеться 37 користувачами (на 1 січня 2020 р.), де 1508,1 тис. га (83,2 \%) надано в користування організаціям Українського товариства мисливців та рибалок (УТМР), 192 тис. га (10,6 \%) - підприємствам Державного лісового агентства України (ДП УЛМГ), 113,5 тис. га (6,3%) - іншим приватним та громадським мисливським організаціям (рис. 2). Термін надання в оренду мисливських угідь становить 14-15 років. Проте повноцінною господарською діяльністю займаються тільки 33 суб'єкти. Причинами є: перебування одного господарства у стані ліквідації, закінчення терміну ліцензії, відсутність по двох господарств звітності (Yavorska \& Sobolevska, 2021).

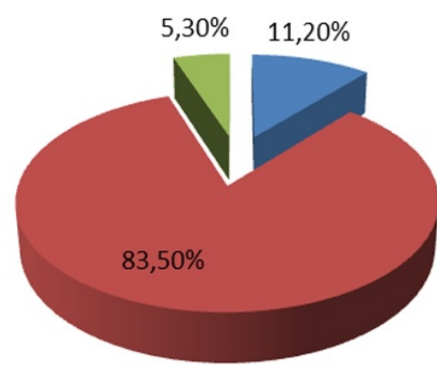

пдпулмг шутмр шнші

2015 рік

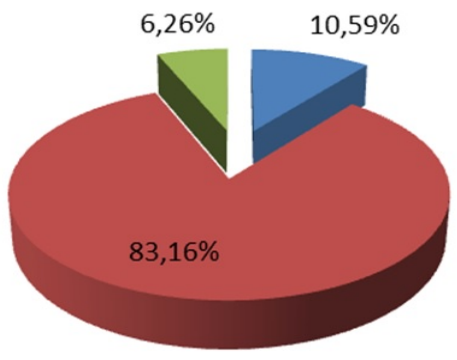

вдулмг вутм ш Інші

2019 рік

Рис. 2. Структура користувачів мисливських угідь Запорізької області

Джерело: складено автором на основі (Statystychna zvitnist Zaporizkoho..., 2020)

Динаміка структури користувачів мисливських угідь Запорізької області показує тенденцію зменшення їх площі у державних господарствах та організаціях УТМР. Натомість збільшується площа угідь у приватних мисливських господарствах, де як свідчить практика, контроль за їх використанням є не таким систематичним та жорстким, як у державних підприємствах. Проте дана тенденція є об’єктивною, оскіль- ки підтверджена успішним досвідом сусідніх європейських країн. Він показує, що значно менша середня площа одного мисливського господарства (3-7 тис. га), яка знаходиться у приватному користуванні, дає можливість їх оптимізувати та вести ефективний розвиток. Аналіз фінансових показників діяльності мисливських господарств Запорізької області свідчить про значний рівень їх збитковості (табл. 1). 
Таблиця 1

Динаміка фінансових показників діяльності мисливських господарств Запорізької області

\begin{tabular}{|c|c|c|c|c|c|c|}
\hline Показники & 2015 & 2016 & 2017 & 2018 & 2019 & $\begin{array}{r}2019 \text { y } \\
\% \text { до } 2015 \\
\end{array}$ \\
\hline $\begin{array}{l}\text { Дохід (надходження) від ведення } \\
\text { мисливського господарства, тис.грн }\end{array}$ & 5750,6 & 6907,1 & 7468,6 & 15526,2 & 10921,4 & 189,92 \\
\hline -в т.ч. на 1 тис.га & 3156,5 & 3779,5 & 4125,4 & 8561 & 6022 & 189,92 \\
\hline $\begin{array}{l}\text { Загальні витрати на ведення ми- } \\
\text { сливського господарства, тис.грн }\end{array}$ & 9106,7 & 10072,2 & 11937,6 & 16807,4 & 15218,3 & 167,11 \\
\hline $\begin{array}{l}\text {-з них витрати на охорону та біотех- } \\
\text { нічні заходи, тис.грн. }\end{array}$ & 2324,0 & 2628,5 & 3058,3 & 3065,3 & 3024,4 & 130,14 \\
\hline -в т.ч. на 1 тис.га & 1275,7 & 1438,3 & 1689,3 & 1690,2 & 1667,6 & 130,14 \\
\hline Рівень окупності витрат, \% & 63,1 & 68,5 & 62,6 & 92,4 & 71,8 & $+8,7$ \\
\hline
\end{tabular}

Джерело: складено автором на основі (Statystychna zvitnist Zaporizkoho..., 2020)

Суттєві фінансові витрати на ведення мисливського господарства призвели до формування у 2019 р. значення показника рівня окупності витрат у розмірі $71,8 \%$. У середньому за п'ять років він становить $71,7 \%$. Треба відмітити, що серед інших регіонів країни, у мисливських господарствах Запорізької області показник окупності витрат $є$ одним із найвищих. Найнижчий рівень окупності спостерігається у Волинській, Київській, Кіровоградській, Черкаській,
Херсонській, Дніпропетровській, Одеській, Миколаївській, Рівненській, Закарпатській, Сумській, ІваноФранківській, Донецькій, Луганській, Харківській, Тернопільській, та Чернівецькій областях (рис. 3). Можна зробити припущення, що діяльність мисливських господарств регіону частково перебуває в тіні, i відповідно, статистичні дані про фінансові показники не завжди відповідають дійсності.

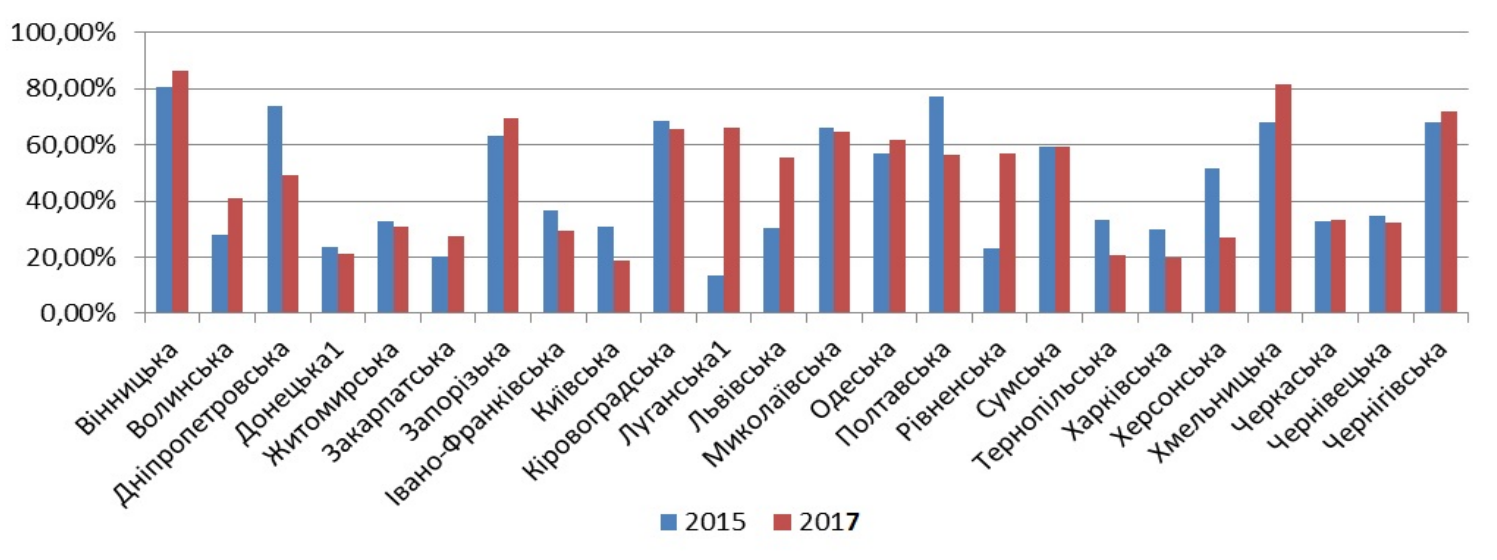

вдпулг путмР пнші

2015 рік

\section{пдпулг шутм ш шші}

2017 рік

Рис. 3. Динаміка рівня окупності витрат за регіонами у 2015 та 2017 рр., \%

*1 Дані за 2015-2019 роки наведено без урахування тимчасово окупованої території АРК, м. Севастополя та частини тимчасово окупованих територій у Донецькій та Луганській областях

Джерело: розроблено автором на основі (Vedennia myslyvskoho hospodarstva..., 2018)

Частково дане припущення можуть підтвердити дані статистичних спостережень у розрізі різних організаційних форм ведення мисливського господарства (табл. 2).

Вони свідчать про найнижчий рівень окупності витрат у користувачів, які відносяться до інших приватних та громадських мисливських організацій. Зокрема, він становить у 2019 році 55, 9 \% порівняно із $63,8 \%$ у організацій Українського товариства мисливців та рибалок та 74,4 \% - підприємствах Державного лісового агентства України. Досить малоймовірно, що приватні користувачі мисливських угідь постійно перебувають у стані збитковості. При цьому жодне із збиткових господарств не відмовляється добровільно від користування мисливськими угіддями, а навпаки, претендує і в подальшому на продовження терміну оренди.

Структура джерел доходів мисливських господарств складається 3:

- плати за відстріл мисливських тварин(продажу ліцензій, відстрільних карток);

- надходжень від реалізації натуральної мисливської продукції;

- надходжень від продажу живих відновлених мисливських тварин; 
- надходжень від вступних, членських та інших внесків членів мисливських товариств;

- надходжень за оренду спеціальних будівель(мисливських будиночків, укриттів тощо), мисливських собак, автотранспорту, обслуговування мисливців тощо;

- грошового еквіваленту оцінки корисності деяких видів диких тварин і птахів в сільському і лісовому господарстві;
- грошового еквіваленту оцінки оздоровчого, культурного(виховного), спортивного і рекреаційного значення мисливського господарства;

- доходів від власної діяльності мисливських господарств;

- спеціальних коштів(надходжень від трофеїв, штрафів, конфіскатів тощо);

- дотацій, спонсорської допомоги тощо.

Таблиця 2

Показники діяльності мисливських господарств Запорізької області за формами ведення станом на 01.01.2020 р.

\begin{tabular}{|c|c|c|c|}
\hline Показники & ДП УЛМГ** & УTMP* & Інші організації*** \\
\hline Площа наданих у користування мисливських угідь, га & 191981 & 1508115 & 100771 \\
\hline Загальні витрати на ведення мисливського господарства, грн. & 1475490 & 12195260 & 1408514 \\
\hline Доходи від ведення мисливського господарства, грн. & 941236 & 9072319 & 787090 \\
\hline Рівень окупності витрат від ведення мисливського господарства,\% & 63,8 & 74,4 & 55,9 \\
\hline
\end{tabular}

*УТМР - Мисливські угіддя Українського товариства мисливців і рибалок;

**ДП УЛМГ - Мисливські угіддя Державного агентства лісових ресурсів України;

***Інші організації - Користувачі інших організаційно-правових форм.

Джерело: розроблено автором на основі (Vedennia myslyvskoho hospodarstva..., 2018; Statystychna zvitnist Zaporizkoho..., 2020)

Згідно ст. 36 Закону України "Про мисливське господарство та полювання" "Надходження коштів від ведення мисливського господарства”. Користувачі мисливських угідь одержують від спеціально уповноваженого центрального органу виконавчої влади у галузі мисливського господарства та полювання або визначеного ним органу ліцензії на добування ведмедя, кабана, лані, оленів благородного та плямистого, козулі, лося, муфлона, білки, бабака, бобра, нутрії вільної, ондатри, куниць лісової та кам'яної, норки американської, тхора лісового за плату, розмір якої визначається за погодженням з центральним органом виконавчої влади 3 питань фінансів (Pro myslyvske hospodarstvo..., 2000).

Кошти за видачу посвідчень мисливця та щорічних контрольних карток обліку добутої дичини і порушень правил полювання зараховуються на рахунок спеціально уповноваженого центрального органу виконавчої влади у галузі мисливського господарства та полювання і використовуються на охорону та відтворення державного мисливського фонду. Зазначені кошти включаються до кошторису доходів і видатків спеціально уповноваженого центрального органу виконавчої влади у галузі мисливського господарства та полювання, і на цю суму зменшується обсяг його фінансування за рахунок Державного бюджету України. На думку Ю. Муравйова, така ситуація є причиною того, що користувачі мисливських угідь недоотримують значну частину фінансових ресурсів, а враховуючи низьку окупність галузі, не мають жодного стимулу для ефективного господарювання (Muraviov, 2019). Це один із багатьох факторів, який не мотивує до діяльності, а іноді спонукає отримувати додаткові надходження не зовсім законними методами.

Проведений аналіз даних дозволяє зробити висновок, що у цілому розвиток продуктивності економічної діяльності мисливського господарства, залежить від самофінансування та самоокупності. Тому у фор- муванні доходів важливу роль також відіграють і інші внески (цільові тадобровільні внески, торгівля та трудоучасть). У цьому випадку під трудоучастю слід розуміти оплату за виконання певної господарської діяльності, наприклад, заготівлі сіна та кормів. Насамперед йдеться про участь мисливців у біотехнічній роботі мисливських господарств. Якщо мисливець не має можливості брати участь у заготівлі кормів, він повинен сплатити додатково до щорічного внеску, внесок трудоучасті. Грошові доходи у вигляді внесків членів товариства складаються 3 трьох етапів. Перший етап основний, його сплачують одноразово кожен рік усі члени товариства, незалежно від того, будуть вони брати участь у полюванні, чи ні. Цей внесок засвідчує приналежність особи до кількісного складу мисливців Другим та третім етапами є відкриття сезону полювання на дику птицю та хутрового звіра (Yavorska, 2013).

Отже мисливські господарства мають можливість отримувати значні доходи від своєї діяльності, але не усі користуються нею. Як показало статистичне спостереження, основними доходами мисливських господарств $є$ реалізація ліцензій, реалізація відстрільних карток на хутрові, реалізація відстрільних карток на пернату дичину, спонсорська допомога та інші надходження. Закордонний досвід ведення мисливського господарства свідчить про більш широкий перелік джерел доходів (Honta \& Muzyka, 2019). Наприклад, у Польщі фінансові надходження від ведення мисливського господарства формуються за рахунок продуктів тваринного походження, проведення полювань для мисливців, які невходять до їхнього товариства, та організації туристичних полювань.

Отже, основним напрямом діяльності мисливських господарств є реалізація ліцензій на добування мисливських тварин. Загальна чисельність тварин і кількість добутих диких тварин у мисливських угіддях Запорізької області наведено в табл. 3 . 
Таблиця 3

Динаміка чисельності та добування диких тварин у мисливських угіддях Запорізької області

\begin{tabular}{ccccccc}
\hline Роки & \multicolumn{2}{c}{ Кількість мисливських тварин(гол.) } & \multicolumn{2}{c}{ Кількість добутих (вилучених) мисливських тварин (гол.) } \\
\hline & $\begin{array}{c}\text { Копитні } \\
\text { тварини }\end{array}$ & $\begin{array}{c}\text { Хутрові } \\
\text { звірі }\end{array}$ & $\begin{array}{c}\text { перната } \\
\text { дичина }\end{array}$ & Копитні тварини & Хутрові звірі & перната дичина \\
\hline 2015 & 1812 & 120097 & 452119 & 52 & 19879 & 75878 \\
2016 & 1742 & 122164 & 423681 & 44 & 20751 & 95770 \\
2017 & 1734 & 122367 & 396084 & 18 & 22734 & 104285 \\
2018 & 1655 & 125298 & 402991 & 8 & 19335 & 108385 \\
2019 & 1772 & 128536 & 434430 & 19 & 23873 & 106782 \\
2019 у \% до & 98 & 107,0 & 96,1 & 36,6 & 120,1 & 140,7 \\
2015 & & &
\end{tabular}

Джерело: розраховано автором на основі (Statystychna zvitnist Zaporizkoho..., 2020)

Найбільш об'єктивним показником ведення мисливського господарства є кількість добування копитних тварин, вартість полювання на яких є значно дорожчою, ніж полювання на пернатих чи хутрових тварин, і становить значну частку доходів мисливських господарств (Bondarenko \& Rizun, 2016). Мисливські господарства європейських країн найбільш орієнтовані на добування копитних тварин. В Україні також найпрестижнішим $є$ ліцензоване полювання на копитних мисливських тварин, які є досить бажаним здобутком для мисливця (кабан, козуля, олень благородний), а особливо їх трофеї. Але проведений аналіз довів, що не всі мисливські господарства використовують свій потенціал і можливість заробити кошти для розвитку галузі. Чисельність добутих копитних в регіоні залишається на низькому рівні. Згідно статистичних даних Запорізької області, кількість добутих копитних у період із 2015 по 2019 рік скоротилася із 52 до 19 , або у 2,7 рази.

На думку більшості вчених, це пов'язано зі зниженням популяції дикого кабана внаслідок поширення африканської чуми свиней (АЧС). Але видовий склад копитних складається не тільки 3 поголів'я дикого кабана. Причинами неефективного ведення мисливського господарства $\epsilon$ недотримання етики полювання, майже відсутнє розведення мисливських звірів і птахів у вольєрах, недосконала регуляція чисельності хижаків і браконьєрське добування дичини, відсутність науково-обгрунтованого управління популяціями мисливських тварин та ін.

Грунтовний аналіз доходів мисливських господарств вимагає прозорості та доступності статистичної інформації, що має свідчити про зацікавленість користувачів і насамперед держави у розвитку цієї галузі. На сьогоднішній момент майже повністю відсутня статистична інформація про фінансові показники діяльності мисливських господарств. Згідно Наказу № 243 від 19.08.2014 Державного комітету статистики України була затверджена форма річної звітності для мисливських господарств 2-тп полювання "Ведення мисливського господарства”. У другому розділі даного звіту наводилися витрати на ведення мисливського господарства і доходи(надходження) від експлуатації мисливських угідь(одним рядком без деталізації). 3 30.08.2017 року форма була змінена на “Звіт про облік, добування та розведення мисливських тварин”, де зазначається лише рух тварин (Pro zatverdzhennia form derzhavnykh..., 2017).

\section{Висновки}

Аналіз динаміки і структури доходів(надходжень) мисливських господарств Запорізької області показує, що їх формування відбувається під дією багатьох негативних факторів, серед яких основними є: високий рівень браконьєрства, тіньова складова економіки, недосконалість нормативно-правової бази та статистичної звітності,скорочення площі мисливських угідь, зниження чисельності добування копитних тварин, недостатня кількість кваліфікованих спеціалістів тощо. Майже повна відсутність державного регулювання мисливської галузі призвела до зниження економічного стимулювання користувачів мисливських угідь у напрямку ефективного i раціонального використання природних ресурсів регіону. У результаті, при наявності природних, географічних, кліматичних та економічних умов для успішного розвитку мисливських господарств Запорізької області, галузь залишається збитковою, хоча у динаміці спостерігається покращення показника окупності витрат. Сучасні тенденції розвитку мисливського господарства в регіоні вимагають реформування цієї сфери за прикладом європейських країн (наприклад збільшення кількості вольєрних господарств із розведення диких мисливських тварин і птахів), виділення основних проблем, що стримують розвиток та розробку дієвих шляхів їх вирішення.

Перспективи подальших досліджень. У подальшому планується дослідити вплив витрат на формування доходів мисливських господарств та підвищення ефективності їх ведення. Особлива увага буде звернена на оплату праці, охорону та біотехнічні заходи та упорядкування мисливських угідь, як основних складових витрат мисливських господарств.

\section{References}

Bondarenko, V. D., \& Rizun, E. M. (2016). Aktualni pytannia stanu i vedennia myslyvskoho hospodarstva v Ukraini ta mozhlyvi napriamky yikh vyrishennia. Naukovi pratsi Lisivnychoi akademii nauk Ukrainy: zbirnyk naukovykh prats, 14, 180-184 doi: 10.15421/411625 (in Ukrainian). 
Haibura, Yu. (2019). Suchasnyi instrumentarii upravlinnia prybutkovistiu pidpryiemstva. Nauka XXI st.: vyklyky ta perspektyvy, 1, 59-76. doi: 10.37406/sXXIcp.2021.v1.59 (in Ukrainian).

Honta, O., \& Muzyka, V. (2019). Yevropeiskyi dos-vid vedennia myslyvskoho hospodarstva: perspektyvy dlia Ukrainy. Problemy i perspektyvy ekonomiky ta upravlinnia, 19(3), 119-125. doi: 10.25140/24115215-2019-3(19)-113-125 (in Ukrainian).

Muraviov, Yu. V. (2019). Doslidzhennia vytrat i dzhe-rel nadkhodzhen vid vedennia myslyvskoho hospodars-tva Lvivskoi oblasti. Naukovyi visnyk NLTU Ukrayiny, 29(4), 50-52. doi: 10.15421/40290410 (in Ukrainian).

Muzyka, V., \& Honta, O. (2020). Otsiniuvannia suchasnoho stanu rozvytku myslyvskoho hospodarstva Ukrainy. Halytskyi ekonomichnyi visnyk, 67(6), 18-32. doi: $\quad 10.33108 /$ galicianvisnyk_tntu2020.06.018 (in Ukrainian).

Ostapenko, Ya. O., \& Morozovskyi, P. A. (2020). Chynnyky vplyvu na formuvannia dokhodu pidpryiemst-va: oblikovo-analitychnyi aspekt. Ekonomichnyi prostir, 154, 115-119. doi: 10.32782/2224-6282/154-21 (in Ukrainian).

Pro myslyvske hospodarstvo ta poliuvannia: Zakon Ukrainy vid 22.02.2000 № 1478-III. URL: http://zakon.rada.gov.ua/laws/show/1478-14 (in Ukrain-ian).

Pro zatverdzhennia form derzhavnykh statystychnykh sposterezhen iz ekolohii, lisovoho ta myslyvskoho hospodarstva: Nakaz Derzhavnoi sluzhby statystyky vid 30.08.2017 № 239. Baza danykh “Zakonodavstvo Ukrainy" / VR Ukrainy. URL: https://zakon.rada.gov.ua/rada/show/v0243832-14 (data zvernennia: 01.09.2021) (in Ukrainian).
Statystychna zvitnist Zaporizkoho oblasnoho upravlinnia lisovoho ta myslyvskoho hospodarstva. Forma 2-TP Myslyvstvo za 2015-2019 rr. (2020). URL: https://zaplis.gov.ua (in Ukrainian).

Torosov, A. S., Zuiev, Ye. S., \& Kharchenko, Yu. V. (2012). Ekonomiko-pravovi aspekty hroshovoi otsinky myslyvstva Kharkiv. UkrNDILHA. Lisnytstvo i ahroli-somelioratsiia, 120, 149-155. URL: https://journals.indexcopernicus.com/api/file/viewByF ileId/465268.pdf (in Ukrainian).

Vedennia myslyvskoho hospodarstva u 2015-2017 rr. (2018). Derzhavna sluzhba statystyky Ukrainy. URL: http://www.ukrstat.gov.ua/ (in Ukrainian).

Voloshyna, O. V. Kordzaiia, I. A., Datsenko, S. M., \& Ulchenko, A. M. (2019). Metodychni pidkhody do anali-zu dokhodiv pidpryiemstva ta faktoriv yikh formuvannia. Efektyvna ekonomika, 6, URL: http://www.economy.nayka.com.ua/?op=1\&z=7119 (data zvernennia: 26.10.2021). doi: 10.32702/23072105-2019.6.47 (in Ukrainian).

Yavorska, A. V. (2013). Ekonomiko-statystychni aspekty vedennia myslyvskoho hospodarstva u Zhyto-myrskii oblasti. "Ekonomichnyi analiz", 13, 409-414. URL:https://www.econa.org.ua/index.php/econa/articl e/download/121/160 (in Ukrainian).

Yavorska, T., \& Sobolevska, O. (2021). Analiz finansovykh pokaznykiv diialnosti myslyvskykh hos-podarstv zaporizkoi oblasti. materialy Vseukrainskoi naukovopraktychnoi internet-konferentsii (m. KamianetsPodilskyi., 19 bereznia 2021 roku), 181-184. URL: http://elar.tsatu.edu.ua/bitstream/123456789/14697/1/3.p df (in Ukrainian). 